\title{
The Impact of State Ownership and Investor Protection Level on Corporate Performance: Cross-Country Analysis
}

\author{
Anastasia N. Stepanova ${ }^{7}$, Stanislav A. Yakovlev ${ }^{8}$
}

In this paper the authors model the impact of state ownership as a component of the corporate financial architecture on corporate performance and conduct a cross-country analysis of this effect in order to identify the geopolitical differences. The cross-country analysis is focused on the level of development of the institutional mechanisms, designed to protect minority shareholders. The major findings of the paper are in line with a number of research papers' results obtained in the developed and emerging markets. The contribution of this paper is the joint analysis of two different factors: state ownership and investor protection level and the development of the corporate performance model taking into account the joint influence of these factors as well as their interrelation.

\section{JEL: G32}

Keywords: state ownership, investor protection, ownership structure, corporate performance

\section{Introduction}

Corporate performance modeling based on the ownership structure measures has become a popular research area within the corporate finance since the end of the 1970s. However, in the recent years the focus has been moved in favour of the complex analysis, which implies the modeling of corporate performance based on the system of structural corporate characteristics. The first papers covering the complex modeling of corporate performance for Russian companies are being published [Ivashkovskaya, Stepanova, 2010].

The study of the state ownership as a component of the corporate financial architecture appears to be especially of interest in light of the global financial crisis of 2008-2009, which resulted in the governments of many countries buying significant equity stakes in the largest companies in order to preserve economic stability. Due to this reason, the following question arises again: how effectively the state as a shareholder is able to create value for such companies and to provide the protection of minority shareholders' interests?

This paper provides an empirical study of the impact of state ownership and level of minority shareholders' protection on corporate performance at the developed and emerging markets.

The sample for the analysis includes over 300 largest non-financial companies from Western and Eastern Europe, including Russia. We studied state ownership and level of investor protection in these companies.

\section{Conception and Research Hypotheses}

A review of the classical papers studying the impact of ownership structure on corporate performance [Jensen, Meckling, 1976; Demsetz, 1983 at al.] has shown that the diffusion of equity capital among a lot of shareholders may result in the reduction of its value due to the emergence of significant agency costs of monitoring. However, when the ownership and control rights are split, presence of a controlling shareholder can significantly reduce the size of such agency costs and serve as a positive signal for minority shareholders.

[Boycko, Shleifer, Vishny, 1996] have demonstrated in their model that having the state as

\footnotetext{
${ }^{7}$ State University - Higher School of Economics, Corporate Finance Center, AnastasiaNStepanova@gmail.com

${ }^{8}$ Morgan Stanley, Investment Banking Division, Stanislav.Yakovlev@morganstanley.com
} 
one of the largest shareholders of a company may negatively affect its corporate performance. The reason of lower corporate performance of state companies is the fact, that they are rather pursuing some social goals (i.e. unemployment) than try to maximize their profit. Although excessive employment is not the only source of lower efficiency of state companies, the authors of the model consider it to be the most wide-spread one.

The analysis of the model of [La Porta et al., 1998] shows, that the level of minority shareholders' protection is another significant factor, affecting corporate performance. When the state is able to provide higher level of legislative protection for the investors, reduction in the share of corporate profit, expropriated by the controlling shareholder, should result in the improvement of corporate performance.

Out of 68 empirical studies, analyzed in the process of reviewing the papers which study the impact of state ownership on corporate performance, in 41 we conclude that private companies are more efficient than public. In 6 papers exactly the opposite results were obtained, which can be explained by some industry specific factors, since in five of those papers utilities were studied. In 21 papers we either could not identify a significant difference in the corporate performance of two types of property or the dependence appeared to be non-monotonous.

The number of studies of the problem of investor protection impact on corporate performance is not that significant. Besides the difficulties related to the need to implement an interdisciplinary approach to the analysis of the effect of investor protection level on corporate performance, relevant sample creation is also an issue. Since the legislation on minority shareholders' protection is usually being developed and approved at the state level, conducting a quality study requires an intercountry sample of companies. Collection of statistically significant number of observations for many developing countries often appears to be almost impossible at all. Consequently, the majority of the papers analyses the impact of investor protection level at the developed markets.

La Porta, Lopez-de-Silanes, Shleifer and Vishny have made the largest contribution to the development of the methodology for the study this problem. In several of their papers the authors analyzed the effect of the level of investor protection on the development of the financial markets and corporate performance based on the spatial sample of a wide range of companies from both developed and emerging markets.

As the proxy for the level of investor protection we have used the standard variables, such as the type of legal system in the country (Roman, Anglo-Saxon or Scandinavian), as well as the specifically designed indices: ADRI - Anti-Director Rights Index [La Porta et al., 1998] and ASDI - Anti-Self-Dealing Index [La Porta et al., 2008]. Since these indices include several evaluation parameters, they provide for higher variability relative to standard measures, such as the type of legal system, which makes their application more effective for the study of the differences in legislative investor protection between the countries. As a result, these indices have achieved significant popularity and are being often used by other authors as a proxy for the level of investor protection. Let us discuss these indices in more detail.

The ADRI index, published in [La Porta et al., 1998], represents a sum of six binary variables. The respective variable takes the value of 1 in case:

-the country allows shareholders to mail their proxy vote;

-shareholders are not required to deposit their shares prior to the General Shareholders' Meeting;

- cumulative voting or proportional representation of minorities on the board of directors is allowed;

-an oppressed minorities mechanism is in place;

-the minimum percentage of share capital that entitles a shareholder to call for an Extraordinary Shareholders' Meeting is less than or equal to ten percent;

-shareholders have preemptive rights that can only be waved by a shareholders meeting.

Thus, the ADRI index can be equal to any number from 0 to 6 with a step of 0.5 . Six corresponds to the maximum level of minority shareholders' protection, zero - to the minimum level. 
The ASDI index was published in [La Porta et al., 2008] and was positioned as a better proxy for the investor protection level, than ADRI index. It can take any value from zero to one. Due to the fact that the questions used in the process of collecting data for the ASDI index were more strictly formalized, the authors could reach the standardization of the results obtained in different countries.

Based on the analysis of the microeconomic models and literature review, we formulated the following hypotheses.

Hypothesis 1: Presence of the state as one of the company's shareholders negatively affects its corporate performance.

Hypothesis 2: Increase in the level of investor protection in the country has a positive effect on the improvement in the corporate performance of its companies.

\section{Model}

One of the most challenging issues of corporate performance modeling is to choose the dependent variable that should properly reflect the strategic performance of the company. In this paper we focus on the market performance measured with the wide popular Tobin's Q coefficient. The key advantage of Tobin's Q is a reflection of market's expectations about the Company's equity value. Using the assumption of the market efficiency, we could say that the market value should on average reflect the intrinsic value of the company.

As for independent variables, we use two proxy variables for state ownership including State Ownership and State Ownership Dummy. We choose ASDI index as one of the most fitted proxy variable for the investor protection level in the country. Besides, we included in the model the multiplication of ASDI and State Ownership Dummy to catch the joint effect of state ownership and investor protection level.

Now, to make the strategic performance model more reliable, we introduce the key financial determinants of Tobin's Q as control variables. They are reflected in the model equation (1) as Financial_Controls vector. Control variables include a proxy variable for the company size measured by a natural logarithm of the total assets ( $\ln$ (Total_Assets)), competition level approximated with ROS (return on sales), sales growth and capital structure measured with Debt-toAssets ratio. To control the level of operating risk we introduce into the model EBITDA Volatility variable, which is calculated as a normalized standard deviation of EBITDA over the [or "in the"] last 5 years. Besides, we included into the model the dummy variables to control the type of legislation system in the country. The independent variables are summarized in Table 1.

The main equation of the model is represented below:

Str_Perf ${ }_{i}=\beta_{0}+\beta_{1}\left(C V_{i}\right)+\beta_{2}\left(S T O_{i}\right)+\beta_{3}\left(I P R_{i}\right)+\beta_{4}\left(S T O_{i} * I P R_{i}\right)+\beta_{5}\left(L O_{i}\right)+\varepsilon_{i}$

where Str_Perf is company's strategic performance indicator;

$\mathrm{CV}$ is a vector of control variables;

STO is a State Ownership indicator;

IPR is an Investor Protection indicator (ASDI Index);

LO is a Legal System dummy variable.

The main assumption of such a model is an exogenous character of all the independent variables. In this paper unlike the number of recent papers e.g. [Ivashkovskaya, Stepanova, 2010] we do not investigate the problem of potential endogenous character of independent variables.

\section{Sample Description}

In this research we used the unique database prepared by the Corporate Finance Center of State University - Higher School of Economics (Moscow, Russia). The database contains the data on ownership structure and corporate governance of Russian and other European companies. The final research sample contains 309 companies from 17 countries of Western and Eastern Europe including Russia. Our sample includes companies representing 11 key sectors of the economy 
accounting for a significant proportion of European countries GDP - telecoms, consumer markets, utilities, metallurgy, oil \& gas, etc.

Ownership structure data was collected manually using the company's annual reports, top bank analyst reports and news from reliable news agencies as of 31 December 2007. The ADRI and ASDI figures were received from [La Porta et al., 2008].

For financial and market data we used Bloomberg as well as Amadeus and Ruslana databases from Van Dijk agency. All the financials were translated to US Dollars using the year-average exchange rate for P\&L financials and year-end rate for balance sheet financials.

The sample used in this research paper is not homogeneous. Some companies included into the sample have extremely different ownership structure as well as financial indicators. On one hand, it seems that such an unbalanced sample is not designed well for the research purposes. On the other hand, it perfectly reflects the market and industry situation in Russia and several European countries. To alleviate this very typical problem we included a number of control variables into the model.

Having analyzed the descriptive statistics we concluded that on average ownership concentration as well as state ownership of European corporations is higher in emerging countries than in developed countries. 94 companies out of 309 have state-affiliated shareholder. Besides, we pointed out that the majority of them have around 5\%, 15-20\% or 50\% level of state ownership. State and state-affiliated companies owns more than $65 \%$ only in $14 \%$ of sample companies.

One more common problem of such type of research is a small number of large transparent companies in the emerging European countries that is insufficient to test the model using regression analysis for each country separately. For example, for 8 out of 17 countries included into the sample we managed to get the high-quality data for less than 10 companies. So, despite the significant geopolitical and market differences among different European countries, it is necessary to find criteria for grouping the countries for the purpose of regression analysis.

In this research we use two criteria for grouping the countries. The first one is the level of economy development, i.e. the countries were divided into two groups: developed and emerging. The second criterion is the type of legal system in the country such as Roman, Anglo-Saxon and Scandinavian.

Belgium, Finland, France, Germany, Italy, Netherlands, Portugal, Spain and Sweden were classified as developed countries. The emerging countries group includes Czech Republic, Estonia, Hungary, Latvia, Lithuania, Poland, Romania and Russia. On average the companies in developed countries are significantly larger than those in emerging countries; consequently they demonstrate lower growth rate and Tobin's Q and higher financial leverage. Besides, companies in developed European countries have lower level of ownership concentration and smaller state equity stakes on average than the emerging countries companies. Nevertheless, the average level of investor protection is almost the same for these two subsamples.

Thus, the existence of significant differences between two subsamples demonstrates the necessity of testing the model separately for developed and emerging countries. Afterwards it seems important to conduct the comparative analysis of the results in order to find the difference between the models of strategic performance in developed and emerging countries.

\section{Results}

The current section of the paper contains our main results and conclusions. Appendixes 4-7 show the results of testing the model (1) with regression analysis tools. It's worth mentioning that we tested the model using two different measures of performance.

First of all, we are going to demonstrate the results of testing the model with Tobin's Q as a dependent variable. Appendix 4 shows the results for the developed markets subsample. The explanatory power of the models ( $\mathrm{R}$ squared coefficient adjusted) fluctuates from $32.6 \%$ to $34.0 \%$ that is quite high level for this type of research.

As we can see, all the six variations of the model demonstrate the low level of significance of 
state ownership variables in the model. Thus, the state ownership has no significant impact on the strategic performance of largest companies in developed European countries measured with Tobin's Q coefficient. These results lead to the rejection of Hypothesis 1 that is in conflict with the results obtained in [Grunfeld et al., 2005] and [Farinos et al., 2006]. In those papers the authors managed to prove the negative influence of state ownership over corporate performance in developed markets. We suppose this difference may be explained by the sample difference, since [Grunfeld et al., 2005] and [Farinos et al., 2006] used the one-country sample (Norway and Spain correspondingly) while we use the international sample. As a result, in this research we spend less attention to the country specialties; we are concentrated on the results on aggregate level of developed / emerging countries.

So, we rejected the Hypothesis 1 for the developed markets. On our opinion, the main reason of such a result is the small equity stakes owned by government in developed European countries ${ }^{9}$. Providing the developed legal system in the country, minor equity stake owned by state-affiliated companies may be insufficient to affect the corporate governance and other mechanisms (even for the officials). Besides, in the most developed countries the problems of lobbying and corruption are not so significant as in the most emerging countries, that alleviates the negative influence of state ownership over corporate performance.

As for the investor protection level, here the positive statically significant relationship was discovered. Ceteris paribus, the increase of ASDI by 0.1 leads to the Tobin's Q increase by 0.08 . Thus, we cannot reject Hypothesis 2 for developed European countries. This result is in line with the conclusions obtained by [La Porta et al., 1997, 1998, 1999, 2008].

Having analyzed the coefficients of the control variables in the model, we concluded that ROS, $\ln$ (Total Assets) and Debt-to-Assets are significant at 1\% level. Return on Sales has positive influence over corporate performance while total assets size and financial leverage level has negative influence.

Now let us review the results of testing the model with Tobin's Q using the emerging markets subsample (presented in Appendix 5). The explanatory power of the models (R squared coefficient adjusted) fluctuates from $23.9 \%$ to $27.0 \%$.

As we can see from the Appendix 5, the coefficients at State Ownership and State Ownership dummy are negative and statistically significant at 5\% level. These results confirm Hypothesis 1 , i.e. the higher the state shareholding in the company, the lower the level of its corporate performance. The most obvious reason of this negative effect is the agency conflict between officials and private shareholders of the company. Being a shareholder of a Company, government through its representatives (officials) tries to accomplish its own goals (e.g. taxes, unemployment level, etc.) which could be in conflict with the main purpose of non-state shareholders (as a rule, value maximization). Officials intervene into the decision-making process; and the strategy skews from the optimal one, that leads to decrease in Company value. This result is in line with the conclusion of Kocenda, Svejnar (2002) and Angelucci et al. (2002) demonstrated the inverse relationship between state ownership and performance of Eastern European companies on country level.

The regression analysis of the corporate performance determinants in emerging countries confirmed the Hypothesis 2 as well. The investor protection level has a statistically significant positive influence upon strategic performance measured with Tobin's Q that is in line with the conclusion of [La Porta et al., 1997, 1998, 1999, 2008]. The coefficient at ASDI depends on the specification of the model: it fluctuates from 0.94 to 1.75 being significant regardless the specification.

As for control variables, the situation is almost the same as for developed countries. We demonstrated that ROS, $\ln$ (Total Assets), Debt-to-Assets and Sales Growth have statistically significant coefficients when we test the model on the data of emerging European countries. Return on Sales and Sales Growth have positive influence on corporate performance while total assets size and financial leverage level has negative influence. The only difference here is a significant

\footnotetext{
${ }^{9}$ In developed countries the average State shareholding in the state-affiliated companies is $26 \%$ while in emerging countries it is over $43 \%$.
} 
influence of Sales Growth over performance of European companies in emerging countries.

In order to control the robustness of the results we developed a number of additional specifications of the model. The most important issue is an application of another performance measure (ROA, return on assets). ROA is an operating indicator, showing rather operational performance (or efficiency) than strategic one. It accounts neither for the growth opportunities, nor for the market expectation about the company's future. The results of model testing with ROA as a dependent variable are presented in Appendixes 6 and 7.

Besides, we doubted the quality of ASDI as an investor protection level proxy, so we tested the model with ADRI variable as well. Finally, it was important to test the basic specification of the model taking into account sector dummies. As a whole, the results of additional modifications testing are similar to the basic model that allowed us to conclude that the empirical results are robust.

\section{Discussion}

To our mind, the most significant contribution of this paper is the joint analysis of two different factors: state ownership and investor protection level and, consequently, the development of the corporate performance model taking into account the joint influence of these factors as well as their interrelation. The second most important contribution is absolutely empirical - we managed to demonstrate the difference between the determinants of corporate performance in developed and emerging European countries. The results obtained are statistically significant and robust.

The paper also poses two important questions. The first one is the problem of potential endogeneity of state ownership in both developed and emerging countries. In this research we used the assumption of exogenous character of the independent variables; and the refusal of this assumption is one of the directions for further investigations. The second one is much more philosophical problem. The conclusion of our research makes us ask a question: what should we do to mitigate the significant negative effect of state ownership in companies in emerging markets?

We hope that the results presented in this paper will be useful for the readers and could be use in the process of investor protection policy development as well as for the purpose of corporate performance maximization. Taking into account a large number of countries in the sample and robustness checks we suppose that these results could be used to make practical implications for different emerging countries.

\section{References}

1. Angelucci, M., Estrin, S., Konings, J., Zolkiewski, Z. (2002), The Effect of Ownership and Competitive Pressure on Firm Performance in Transition Countries: Micro Evidence from Bulgaria, Romania and Poland, William Davidson Working Paper Number 43, January 2002.

2. Berle, A. A. and Means, G. C. (1932), The Modern Corporation and Private Property, New York: MacMillan.

3. Boycko, M., Shleifer, A. and Vishny, R. (1996), A Theory of Privatization, Economic Journal 1996, 106(435).

4. Demsetz, H. (1983), The Structure of Ownership and the Theory of the Firm, Journal of Law and Economics, vol. 26, No.2.

5. Farinos, J. E., Garcia, C. J., Ibanez, A. M. (2006), Operating and Stock Market Performance of State-owned Enterprise Privatizations: The Spanish Experience, SSRN Paper.

6. Grunfeld, L. A., Benito, G.R.G., Goldeng, E. (2005), The Inferior Performance of State Owned Enterprises: Is it due to Ownership or Market Structure? SSRN Paper.

7. Ivashkovskaya, I.V., Stepanova ,A.N. (2010), Does strategic corporate performance depend on corporate financial architecture? Empirical study of European, Russian and other emerging market's firms // Journal of Management and Governance. Online First 
Publication. 2010 - February, 1-14.

8. Jensen, M. C., Meckling, W. H. (1976), Theory of the Firm: Managerial Behavior, Agency Costs, and Ownership Structure, Journal of Financial Economics, 3(4).

9. Kocenda, E., Svejnar, J. (2002), The effects of Ownership Forms and Concentration on Firm Performance after Large-Scale Privatization, SSRN Paper.

10. La Porta, R., Lopez-de-Silanes, F. (1997), Benefits of Privatization: Evidence from Mexico, NBER working paper No. 6215.

11. La Porta, R., Lopez-de-Silanes, F., Shleifer, A. and Vishny, R. (1997), Legal Determinants of External Finance, Journal of Finance, 52, 1131-1150.

12. La Porta, R., Lopez-de-Silanes, F., Shleifer, A. and Vishny, R. (1998), Law and Finance, Journal of Political Economy, 106, 1113-55.

13. La Porta, R., Lopez-de-Silanes, F., Shleifer, A. and Vishny, R. (1999), Investor Protection: Origins, Consequences, Reform, Harvard University, manuscript.

14. La Porta, R., Lopez-de-Silanes, F., Shleifer, A. and Vishny, R. (2008), The law and economics of self-dealing, Journal of Financial Economics, 88 (2008), 430-465.

15. Leland, H. E., Pyle, D. H. (1977), Informational Asymmetries, Financial Structure, and Financial Intermediation, Journal of Finance, Vol. 32, No.2, 371-387.

16. Myers S. (1999), Financial Architecture, European Financial Management, 5, 113-141.

17. Shirley, M. M. and Walsh, P. (2000), Public Versus Private Ownership: The Current State of the Debate, SSRN Paper.

\section{Appendix 1. Variables description}

In the Table below the definition of all the variables used in the research are presented. Total Assets are measured in US dollars. All the data were collected as of 31 December 2007.

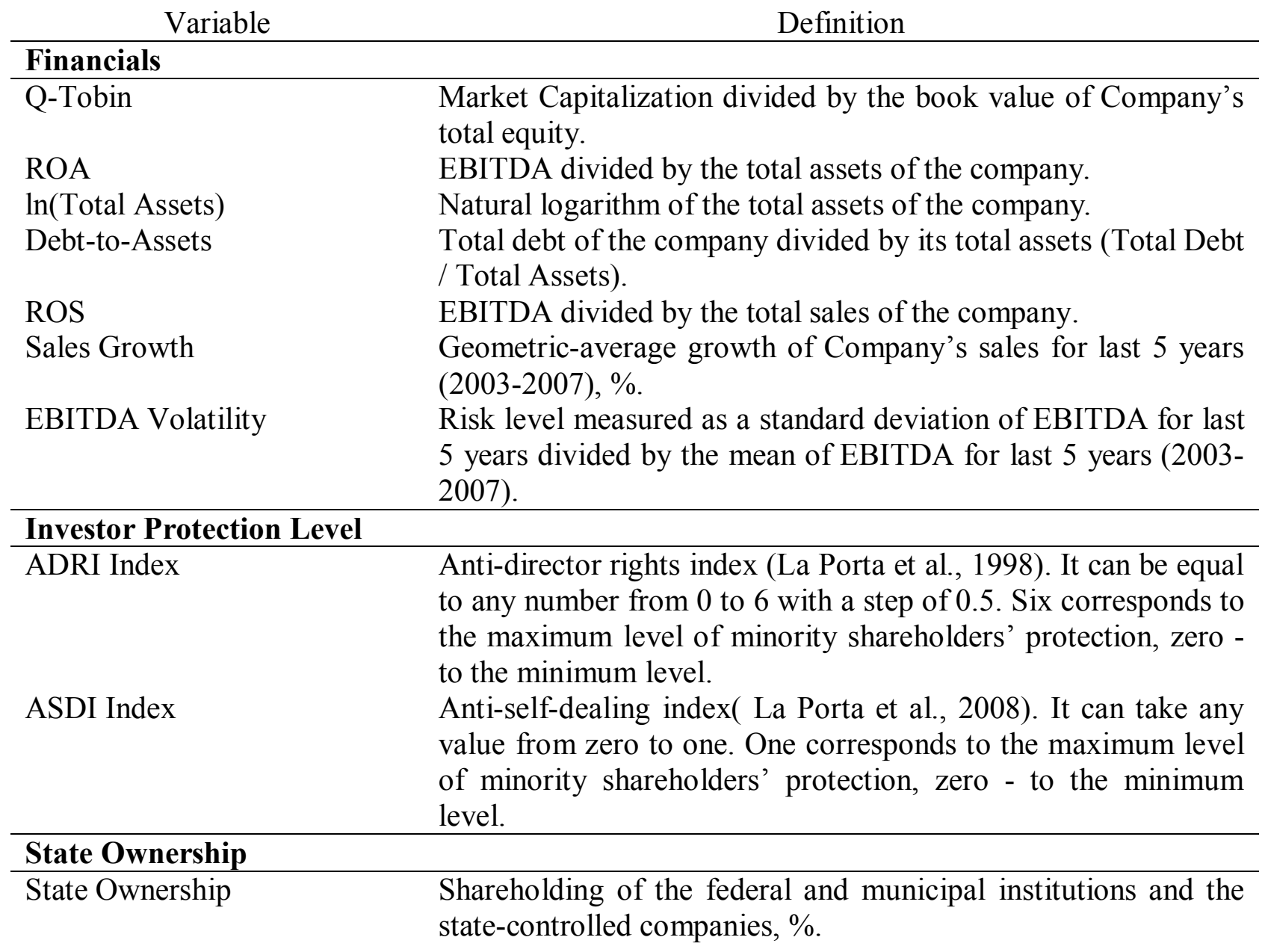


Variable

State Ownership Dummy

Ownership Concentration

Sector dummy variables

Dummy_Ind_Automotive

Dummy_Ind_Chemicals

Dummy_Ind_Manufacturing

Dummy_Ind_Media

Dummy_Ind_Metals_Mining

Dummy_Ind_Oil_Gas

Dummy_Ind_Real_Estate

Dummy_Ind_Telecom

Dummy_Ind_Transport

Dummy_Ind_Utilities

Dummy_Ind_Consumer

\section{Definition}

Dummy variable equals 1 if state or state-affiliated company holds the equity stake in the Company and equals 0 otherwise. Total shareholding of the three major shareholders, $\%$.

Dummy variable equals 1 if the company operates in the automotive sector and equals 0 otherwise.

Dummy variable equals 1 if the company operates in the chemicals sector and equals 0 otherwise.

Dummy variable equals 1 if the company operates in the manufacturing sector and equals 0 otherwise.

Dummy variable equals 1 if the company operates in the media sector and equals 0 otherwise.

Dummy variable equals 1 if the company operates in the metals and mining sector and equals 0 otherwise.

Dummy variable equals 1 if the company operates in the oil and gas sector and equals 0 otherwise.

Dummy variable equals 1 if the company operates in the real estate sector and equals 0 otherwise.

Dummy variable equals 1 if the company operates in the telecommunication sector and equals 0 otherwise.

Dummy variable equals 1 if the company operates in the transportation sector and equals 0 otherwise.

Dummy variable equals 1 if the company operates in the utilities sector and equals 0 otherwise.

Dummy variable equals 1 if the company operates in the consumer and retail sector and equals 0 otherwise.

\section{Legal System Dummy variables}

Dummy_Legal_English

Dummy_Legal_French

Dummy variable equals 1 if the company operates in the country with Anglo-Saxon legal system and equals 0 otherwise.

Dummy_Legal_German

\section{Country dummy variables}

Dummy_Country_Belgium

Dummy_Country_Czech

Dummy_Country_Estonia

Dummy_Country_Finland

Dummy_Country_France

Dummy_Country_Germany

Dummy_Country_Hungary

Dummy_Country_Italy

Dummy_Country_Latvia
Dummy variable equals 1 if the company operates in the country with Roman legal system and equals 0 otherwise.

Dummy variable equals 1 if the company operates in the country with Scandinavian legal system and equals 0 otherwise.

Dummy variable equals 1 if the company operates in Belgium and equals 0 otherwise.

Dummy variable equals 1 if the company operates in Czech Republic and equals 0 otherwise.

Dummy variable equals 1 if the company operates in Estonia and equals 0 otherwise.

Dummy variable equals 1 if the company operates in Finland and equals 0 otherwise.

Dummy variable equals 1 if the company operates in France and equals 0 otherwise.

Dummy variable equals 1 if the company operates in Germany and equals 0 otherwise.

Dummy variable equals 1 if the company operates in Hungary and equals 0 otherwise.

Dummy variable equals 1 if the company operates in Italy and equals 0 otherwise.

Dummy variable equals 1 if the company operates in Latvia and 
Variable

Dummy_Country_Lithuania

Dummy_Country_Netherlands

Dummy_Country_Poland

Dummy_Country_Portugal

Dummy_Country_Romania

Dummy_Country_Russia

Dummy_Country_Spain

Dummy_Country_Sweden

Developed Markets Dummy

Emerging Markets Dummy equals 0 otherwise.

Definition

Dummy variable equals 1 if the company operates in Lithuania and equals 0 otherwise.

Dummy variable equals 1 if the company operates in Netherlands and equals 0 otherwise.

Dummy variable equals 1 if the company operates in Poland and equals 0 otherwise.

Dummy variable equals 1 if the company operates in Portugal and equals 0 otherwise.

Dummy variable equals 1 if the company operates in Romania and equals 0 otherwise.

Dummy variable equals 1 if the company operates in Russia and equals 0 otherwise.

Dummy variable equals 1 if the company operates in Spain and equals 0 otherwise.

Dummy variable equals 1 if the company operates in Sweden and equals 0 otherwise.

Dummy variable equals 1 if the company operates in a developed country and equals 0 otherwise.

Dummy variable equals 1 if the company operates in an emerging country and equals 0 otherwise.

\section{Appendix 2. Descriptive statistics}

In the Table below you can see the descriptive statistics of key variables previously winsorized.

\begin{tabular}{lcccccccc}
\hline \multicolumn{1}{c}{ Variable } & Mean & Min & Max & Median & $\begin{array}{c}\text { Standard } \\
\text { Deviation }\end{array}$ & Asymmetry & Excess & $\begin{array}{c}\text { N of } \\
\text { observations }\end{array}$ \\
\hline Q-Tobin & & & & & & & & \\
ROA & 1.31 & 0.10 & 10.10 & 1.00 & 1.23 & 3.08 & 18.22 & 309 \\
& 0.14 & 0.00 & 0.42 & 0.12 & 0.09 & 0.90 & 3.77 & 306 \\
ROS & & & & & & & & \\
ln(Total Assets) & 0.22 & 0.00 & 0.81 & 0.18 & 0.16 & 1.55 & 5.65 & 306 \\
Debt-to-Assets & 8.45 & 4.09 & 12.27 & 8.66 & 2.11 & -0.31 & 2.29 & 309 \\
Sales growth & 0.26 & 0.00 & 0.78 & 0.24 & 0.17 & 0.58 & 2.91 & 309 \\
EBITDA Volatility & 0.17 & -0.18 & 0.68 & 0.14 & 0.16 & 0.76 & 3.87 & 309 \\
Emerging & 0.48 & 0.04 & 7.92 & 0.31 & 0.95 & 6.68 & 51.05 & 309 \\
Dummy & & & & & & & & \\
State Ownership & 0.48 & 0.00 & 1.00 & 0.00 & 0.50 & 0.07 & 1.01 & 309 \\
State & 0.11 & 0.00 & 0.85 & 0.00 & 0.21 & 2.07 & 6.35 & 309 \\
Dummy Ownership & & & & & & & & \\
ASDI Index & 0.30 & 0.00 & 1.00 & 0.00 & 0.46 & 0.85 & 1.72 & 309 \\
ADRI Index & 0.37 & 0.18 & 0.54 & 0.38 & 0.08 & -0.62 & 2.84 & 303 \\
\hline & 3.53 & 2.00 & 5.00 & 3.50 & 0.91 & -0.30 & 2.43 & 303 \\
\hline
\end{tabular}




\section{Appendix 3. Descriptive statistics by country}

In the Table below the means of key variables by countries are presented.

\begin{tabular}{|c|c|c|c|c|c|c|c|c|c|c|c|c|}
\hline 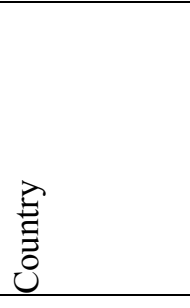 & 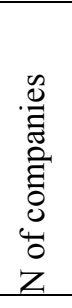 & 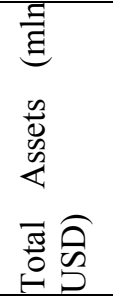 & 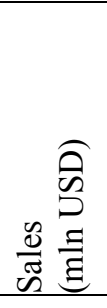 & 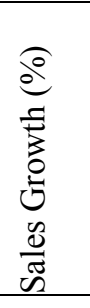 & $\begin{array}{l}0 \\
0 \\
0 \\
0 \\
0 \\
0 \\
0 \\
0 \\
0 \\
0 \\
\frac{1}{1} \\
0 \\
0 \\
0\end{array}$ & 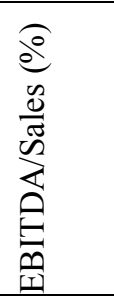 & 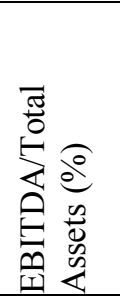 & $\begin{array}{l}\cdot \\
0 \\
0 \\
\dot{0}\end{array}$ & 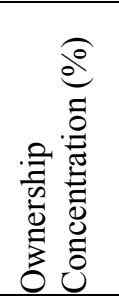 & 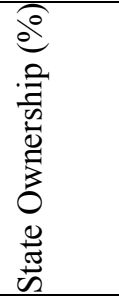 & 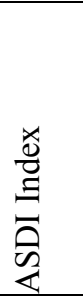 & 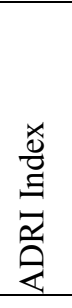 \\
\hline Belgium & 7 & 15706 & 11436 & $5 \%$ & $19.0 \%$ & $23.5 \%$ & $19.4 \%$ & 2.9 & $47.6 \%$ & $15.3 \%$ & 0.54 & 3.00 \\
\hline Czech Rep. & 7 & 5065 & 2950 & $23 \%$ & $29.9 \%$ & $29.7 \%$ & $15.0 \%$ & 1.3 & $59.6 \%$ & $0.0 \%$ & 0.33 & 4.00 \\
\hline Estonia & 6 & 592 & 35 & $32 \%$ & $28.9 \%$ & $17.9 \%$ & $1.2 \%$ & 1.2 & $66.7 \%$ & $5.8 \%$ & N/A & $\mathrm{N} / \mathrm{A}$ \\
\hline Finland & 5 & 12174 & 23556 & $17 \%$ & $21.4 \%$ & $10.3 \%$ & $22.7 \%$ & 1.3 & $27.4 \%$ & $1.0 \%$ & 0.46 & 3.50 \\
\hline France & 48 & 46723 & 30995 & $9 \%$ & $22.1 \%$ & $19.5 \%$ & $12.7 \%$ & 1.1 & $36.4 \%$ & $8.3 \%$ & 0.38 & 3.50 \\
\hline Germany & 36 & 53564 & 36359 & $9 \%$ & $24.9 \%$ & $16.6 \%$ & $13.5 \%$ & 1.1 & $30.8 \%$ & $5.3 \%$ & 0.28 & 3.50 \\
\hline Hungary & 12 & 2251 & 2100 & $1 \%$ & $12.2 \%$ & $27.0 \%$ & $10.9 \%$ & 1.4 & $56.8 \%$ & $0.0 \%$ & 0.18 & 2.00 \\
\hline Italy & 20 & 36482 & 20570 & $14 \%$ & $35.4 \%$ & $29.5 \%$ & $13.9 \%$ & 0.8 & $48.6 \%$ & $9.3 \%$ & 0.42 & 2.00 \\
\hline Latvia & 5 & 463 & 389 & $18 \%$ & $21.9 \%$ & $29.4 \%$ & $25.4 \%$ & 0.6 & $85.6 \%$ & $0.0 \%$ & 0.32 & 4.00 \\
\hline Lithuania & 7 & 459 & 85 & $14 \%$ & $25.4 \%$ & $17.9 \%$ & $4.0 \%$ & 0.8 & $76.3 \%$ & $20.3 \%$ & 0.36 & 4.00 \\
\hline Netherlands & 11 & 23642 & 21767 & $2 \%$ & $24.3 \%$ & $15.6 \%$ & $14.7 \%$ & 1.4 & $22.7 \%$ & $0.0 \%$ & 0.20 & 2.50 \\
\hline Poland & 21 & 2958 & 2550 & $15 \%$ & $18.8 \%$ & $18.2 \%$ & $9.6 \%$ & 1.3 & $53.7 \%$ & $8.7 \%$ & 0.29 & 2.00 \\
\hline Portugal & 4 & 20507 & 10808 & $8 \%$ & $40.4 \%$ & $36.5 \%$ & $14.2 \%$ & 2.2 & $51.0 \%$ & $6.3 \%$ & 0.44 & 2.50 \\
\hline Romania & 18 & 1011 & 757 & $22 \%$ & $32.1 \%$ & $13.9 \%$ & $9.9 \%$ & 1.4 & $74.9 \%$ & $22.5 \%$ & 0.44 & 5.00 \\
\hline Russia & 73 & 11409 & 7250 & $34 \%$ & $25.5 \%$ & $25.4 \%$ & $18.0 \%$ & 1.7 & $66.0 \%$ & $17.6 \%$ & 0.44 & 4.00 \\
\hline Spain & 23 & 36801 & 16204 & $15 \%$ & $36.2 \%$ & $31.9 \%$ & $13.9 \%$ & 1.1 & $52.4 \%$ & $10.0 \%$ & 0.37 & 5.00 \\
\hline Sweden & 6 & 3639 & 412 & $18 \%$ & $36.0 \%$ & $20.7 \%$ & $2.0 \%$ & 1.0 & $35.7 \%$ & $8.3 \%$ & 0.33 & 3.50 \\
\hline Total & 309 & 23516 & 15291 & $18 \%$ & $26.0 \%$ & $22.4 \%$ & $13.7 \%$ & 1.3 & $51.3 \%$ & $10.5 \%$ & 0.37 & 3.53 \\
\hline
\end{tabular}




\section{Appendix 4. Results of testing the strategic performance model using the developed countries subsample}

The table shows the results of cross-section regressions, where the dependent variable is the Tobin's Q coefficient. The definitions of the variables appear in Appendix 1. The sample consists of 160 firms operating in developed European countries. The numbers in parentheses are standard errors after Newey-West adjustment. ${ }^{* * *}, * *$ and $*$ indicate significance at the $1 \%, 5 \%$ and $10 \%$ levels, respectively.

\begin{tabular}{|c|c|c|c|c|c|c|}
\hline & 1 & 2 & 3 & 4 & 5 & 6 \\
\hline ROS & $\begin{array}{l}2.6428^{* * *} \\
(0.8316)\end{array}$ & $\begin{array}{l}2.6027^{* * *} \\
(0.8291)\end{array}$ & $\begin{array}{l}2.6151^{* * *} \\
(0.8304)\end{array}$ & $\begin{array}{l}2.6505^{* * *} \\
(0.8250)\end{array}$ & $\begin{array}{l}2.6238^{* * *} \\
(0.8160)\end{array}$ & $\begin{array}{l}2.6106^{* * *} \\
(0.8225)\end{array}$ \\
\hline $\ln$ (Total Assets) & $\begin{array}{l}-0.2934 * * * \\
(0.0658)\end{array}$ & $\begin{array}{l}-0.2969 * * * \\
(0.0718)\end{array}$ & $\begin{array}{l}-0.3215^{* * *} \\
(0.0681)\end{array}$ & $\begin{array}{l}-0.3170^{* * *} \\
(0.0725)\end{array}$ & $\begin{array}{l}-0.3204 * * * \\
(0.0783)\end{array}$ & $\begin{array}{l}-0.3220^{* * *} \\
(0.0733)\end{array}$ \\
\hline Debt-to-Assets & $\begin{array}{l}-2.2665^{* * *} \\
(0.6467)\end{array}$ & $\begin{array}{l}-2.2805 * * * \\
(0.6183)\end{array}$ & $\begin{array}{l}-2.1835^{* * *} \\
(0.6572)\end{array}$ & $\begin{array}{l}-2.1878 * * * \\
(0.6576)\end{array}$ & $\begin{array}{l}-2.1883 * * * \\
(0.6356)\end{array}$ & $\begin{array}{l}-2.1827 * * * \\
(0.6515)\end{array}$ \\
\hline Sales Growth & $\begin{array}{l}0.4209 \\
(1.0013)\end{array}$ & $\begin{array}{l}0.3605 \\
(1.0186)\end{array}$ & $\begin{array}{l}0.7809 \\
(0.8470)\end{array}$ & $\begin{array}{l}0.8044 \\
(0.8367)\end{array}$ & $\begin{array}{l}0.7851 \\
(0.8413)\end{array}$ & $\begin{array}{l}0.7787 \\
(0.8474)\end{array}$ \\
\hline EBITDA Volatility & $\begin{array}{l}-0.7451 \\
(0.4966)\end{array}$ & $\begin{array}{l}-0.7218 \\
(0.5059)\end{array}$ & $\begin{array}{c}-0.9232^{*} \\
(0.5115)\end{array}$ & $\begin{array}{l}-0.9265^{*} \\
(0.5083)\end{array}$ & $\begin{array}{l}-0.9222^{*} \\
(0.5184)\end{array}$ & $\begin{array}{c}-0.9230^{*} \\
(0.5124)\end{array}$ \\
\hline State Ownership & & $\begin{array}{l}-0.1396 \\
(0.7931)\end{array}$ & & & $\begin{array}{l}-0.0404 \\
(0.8059)\end{array}$ & \\
\hline State Ownership Dummy & $\begin{array}{l}-0.1414 \\
(0.1982)\end{array}$ & & & $\begin{array}{l}-0.0744 \\
(0.2100)\end{array}$ & & \\
\hline ASDI Index & & & $\begin{array}{l}0.8069^{* *} \\
(0.4043)\end{array}$ & $\begin{array}{l}0.6876 \\
(1.0832)\end{array}$ & $\begin{array}{l}0.7967^{*} \\
(0.4658)\end{array}$ & $\begin{array}{l}0.8255 \\
(1.1387)\end{array}$ \\
\hline $\begin{array}{l}\text { State Ownership Dummy * } \\
\text { ASDI Index }\end{array}$ & & & & & & $\begin{array}{l}-0.0250 \\
(0.6770)\end{array}$ \\
\hline Industry Dummies & No & No & No & No & No & No \\
\hline Country Dummies & No & No & No & No & No & No \\
\hline Legal Origin Dummies & Yes & Yes & Yes & Yes & Yes & Yes \\
\hline $\begin{array}{l}\mathrm{N} \\
\text { adj. R-sq }\end{array}$ & $\begin{array}{l}160 \\
0.328\end{array}$ & $\begin{array}{l}160 \\
0.326\end{array}$ & $\begin{array}{l}160 \\
0.340\end{array}$ & $\begin{array}{l}160 \\
0.337\end{array}$ & $\begin{array}{l}160 \\
0.336\end{array}$ & $\begin{array}{l}160 \\
0.336\end{array}$ \\
\hline
\end{tabular}




\section{Appendix 5. Results of testing the strategic performance model using the emerging countries subsample}

The table shows the results of cross-section regressions, where the dependent variable is the Tobin's Q coefficient. The definitions of the variables appear in Appendix 1. The sample consists of 146 firms operating in emerging European countries. The numbers in parentheses are standard errors after Newey-West adjustment. $* * *, * *$ and $*$ indicate significance at the $1 \%, 5 \%$ and $10 \%$ levels, respectively.

\begin{tabular}{|c|c|c|c|c|c|c|}
\hline & 1 & 2 & 3 & 4 & 5 & 6 \\
\hline ROS & $\begin{array}{l}1.9373 * * * \\
(0.6816)\end{array}$ & $\begin{array}{l}1.9794 * * * \\
(0.6802)\end{array}$ & $\begin{array}{l}1.9149 * * * \\
(0.7037)\end{array}$ & $\begin{array}{l}1.8687 * * * \\
(0.7031)\end{array}$ & $\begin{array}{l}1.9260 * * * \\
(0.6997)\end{array}$ & $\begin{array}{l}1.8783 * * * \\
(0.7026)\end{array}$ \\
\hline $\ln$ (Total Assets) & $\begin{array}{l}-0.1642 * * * \\
(0.0431)\end{array}$ & $\begin{array}{l}-0.1631 * * * \\
(0.0428)\end{array}$ & $\begin{array}{l}-0.1858 * * * \\
(0.0469)\end{array}$ & $\begin{array}{l}-0.1694 * * * \\
(0.0463)\end{array}$ & $\begin{array}{l}-0.1678 * * * \\
(0.0462)\end{array}$ & $\begin{array}{l}-0.1693 * * * \\
(0.0464)\end{array}$ \\
\hline Debt-to-Assets & $\begin{array}{l}-1.6175^{* * *} \\
(0.4179)\end{array}$ & $\begin{array}{l}-1.6679 * * * \\
(0.4218)\end{array}$ & $\begin{array}{l}-1.5921 * * * \\
(0.4459)\end{array}$ & $\begin{array}{l}-1.7029 * * * \\
(0.4384)\end{array}$ & $\begin{array}{l}-1.7307 * * * \\
(0.4488)\end{array}$ & $\begin{array}{l}-1.7230 * * * \\
(0.4357)\end{array}$ \\
\hline Sales Growth & $\begin{array}{l}1.9308^{* * *} \\
(0.5202)\end{array}$ & $\begin{array}{l}1.9421^{* * *} \\
(0.5005)\end{array}$ & $\begin{array}{l}2.1909^{* * *} \\
(0.5827)\end{array}$ & $\begin{array}{l}1.9109^{* * *} \\
(0.5624)\end{array}$ & $\begin{array}{l}1.9494 * * * \\
(0.5411)\end{array}$ & $\begin{array}{l}1.8930^{* * *} \\
(0.5581)\end{array}$ \\
\hline EBITDA Volatility & $\begin{array}{l}-0.0941 \\
(0.0683)\end{array}$ & $\begin{array}{l}-0.0921 \\
(0.0676)\end{array}$ & $\begin{array}{l}-0.0847 \\
(0.0655)\end{array}$ & $\begin{array}{l}-0.1001 \\
(0.0705)\end{array}$ & $\begin{array}{l}-0.0964 \\
(0.0693)\end{array}$ & $\begin{array}{l}-0.0995 \\
(0.0704)\end{array}$ \\
\hline State Ownership & & $\begin{array}{l}-0.7443 * * \\
(0.3023)\end{array}$ & & & $\begin{array}{l}-0.7640^{* *} \\
(0.3011)\end{array}$ & \\
\hline State Ownership Dummy & $\begin{array}{l}-0.3592^{* *} \\
(0.1780)\end{array}$ & & & $\begin{array}{l}-0.3975 * * \\
(0.1842)\end{array}$ & & \\
\hline ASDI Index & & & $\begin{array}{l}0.9357 * * \\
(0.4391)\end{array}$ & $\begin{array}{l}1.7541^{*} \\
(1.0426)\end{array}$ & $\begin{array}{l}1.3013 \\
(1.6514)\end{array}$ & $\begin{array}{l}1.7537 * * \\
(0.8230)\end{array}$ \\
\hline $\begin{array}{l}\text { State Ownership Dummy * } \\
\text { ASDI Index }\end{array}$ & & & & & & $\begin{array}{l}-1.0078^{* *} \\
(0.4865)\end{array}$ \\
\hline Industry Dummies & No & No & No & No & No & No \\
\hline Country Dummies & No & No & No & No & No & No \\
\hline Legal Origin Dummies & Yes & Yes & Yes & Yes & Yes & Yes \\
\hline $\mathrm{N}$ & 146 & 146 & 140 & 140 & 140 & 140 \\
\hline adj. R-sq & 0.260 & 0.264 & 0.239 & 0.258 & 0.257 & 0.270 \\
\hline
\end{tabular}


Appendix 6. Results of testing the corporate performance model using the developed countries subsample

The table shows the results of cross-section regressions, where the dependent variable is ROA. The definitions of the variables appear in Appendix 1. The sample consists of 160 firms operating in developed European countries. The numbers in parentheses are standard errors after Newey-West adjustment. $* * *, * *$ and $*$ indicate significance at the $1 \%, 5 \%$ and $10 \%$ levels, respectively.

\begin{tabular}{|c|c|c|c|c|c|c|}
\hline & 1 & 2 & 3 & 4 & 5 & 6 \\
\hline ROS & $\begin{array}{l}0.2271^{* * *} \\
(0.0428)\end{array}$ & $\begin{array}{l}0.2322 * * * \\
(0.0432)\end{array}$ & $\begin{array}{l}0.2157^{* * *} \\
(0.0431)\end{array}$ & $\begin{array}{l}0.2271 * * * \\
(0.0429)\end{array}$ & $\begin{array}{l}0.2324 * * * \\
(0.0431)\end{array}$ & $\begin{array}{l}0.2250^{* * *} \\
(0.0428)\end{array}$ \\
\hline $\ln$ (Total Assets) & $\begin{array}{l}-0.0060 \\
(0.0047)\end{array}$ & $\begin{array}{l}-0.0053 \\
(0.0049)\end{array}$ & $\begin{array}{l}-0.0074 \\
(0.0050)\end{array}$ & $\begin{array}{l}-0.0060 \\
(0.0050)\end{array}$ & $\begin{array}{l}-0.0055 \\
(0.0052)\end{array}$ & $\begin{array}{l}-0.0064 \\
(0.0050)\end{array}$ \\
\hline Debt-to-Assets & $\begin{array}{l}-0.2396^{* * *} \\
(0.0371)\end{array}$ & $\begin{array}{l}-0.2481 * * * \\
(0.0376)\end{array}$ & $\begin{array}{l}-0.2381 * * * \\
(0.0384)\end{array}$ & $\begin{array}{l}-0.2395 * * * \\
(0.0384)\end{array}$ & $\begin{array}{l}-0.2474 * * * \\
(0.0391)\end{array}$ & $\begin{array}{l}-0.2397 * * * \\
(0.0385)\end{array}$ \\
\hline Sales Growth & $\begin{array}{l}0.1455^{* * *} \\
(0.0491)\end{array}$ & $\begin{array}{l}0.1430^{* * *} \\
(0.0502)\end{array}$ & $\begin{array}{l}0.1385^{* * *} \\
(0.0522)\end{array}$ & $\begin{array}{l}0.1461 * * * \\
(0.0510)\end{array}$ & $\begin{array}{l}0.1465^{* * *} \\
(0.0520)\end{array}$ & $\begin{array}{l}0.1431 * * * \\
(0.0511)\end{array}$ \\
\hline EBITDA Volatility & $\begin{array}{l}-0.0722 * * \\
(0.0338)\end{array}$ & $\begin{array}{l}-0.0679 * * \\
(0.0340)\end{array}$ & $\begin{array}{l}-0.0714^{*} \\
(0.0368)\end{array}$ & $\begin{array}{l}-0.0725^{* *} \\
(0.0357)\end{array}$ & $\begin{array}{l}-0.0695^{*} \\
(0.0359)\end{array}$ & $\begin{array}{l}-0.0718^{* *} \\
(0.0360)\end{array}$ \\
\hline State Ownership & & $\begin{array}{l}-0.0780^{* *} \\
(0.0362)\end{array}$ & & & $\begin{array}{l}-0.0771 * * \\
(0.0370)\end{array}$ & \\
\hline State Ownership Dummy & $\begin{array}{l}-0.0240^{* *} \\
(0.0116)\end{array}$ & & & $\begin{array}{l}-0.0239^{* *} \\
(0.0116)\end{array}$ & & \\
\hline ASDI Index & & & $\begin{array}{l}0.0422^{*} \\
(0.0239)\end{array}$ & $\begin{array}{l}0.0040 \\
(0.1171)\end{array}$ & $\begin{array}{l}0.0227^{*} \\
(0.0129)\end{array}$ & $\begin{array}{l}0.0035 \\
(0.1179)\end{array}$ \\
\hline $\begin{array}{l}\text { State Ownership Dummy * } \\
\text { ASDI Index }\end{array}$ & & & & & & $\begin{array}{l}-0.0521 \\
(0.0329)\end{array}$ \\
\hline Industry Dummies & No & No & No & No & No & No \\
\hline Country Dummies & No & No & No & No & No & No \\
\hline Legal Origin Dummies & Yes & Yes & Yes & Yes & Yes & Yes \\
\hline $\begin{array}{l}\mathrm{N} \\
\text { adj. R-sq }\end{array}$ & $\begin{array}{l}160 \\
0.361\end{array}$ & $\begin{array}{l}160 \\
0.365\end{array}$ & $\begin{array}{l}160 \\
0.344\end{array}$ & $\begin{array}{l}160 \\
0.357\end{array}$ & $\begin{array}{l}160 \\
0.361\end{array}$ & $\begin{array}{l}160 \\
0.352\end{array}$ \\
\hline
\end{tabular}


Appendix 7. Results of testing the corporate performance model using the emerging countries subsample

The table shows the results of cross-section regressions, where the dependent variable is ROA. The definitions of the variables appear in Appendix 1. The sample consists of 146 firms operating in emerging European countries. The numbers in parentheses are standard errors after Newey-West adjustment. ${ }^{* *}, * *$ and $*$ indicate significance at the $1 \%, 5 \%$ and $10 \%$ levels, respectively.

\begin{tabular}{|c|c|c|c|c|c|c|}
\hline & 1 & 2 & 3 & 4 & 5 & 6 \\
\hline ROS & $0.2337 * * *$ & $0.2348 * * *$ & $0.2418 * * *$ & $0.2398 * * *$ & $0.2420 * * *$ & $0.2405 * * *$ \\
\hline & $(0.0601)$ & $(0.0598)$ & $(0.0565)$ & $(0.0574)$ & $(0.0571)$ & $(0.0572)$ \\
\hline $\ln$ (Total Assets) & $0.0178 * * *$ & $0.0175 * * *$ & $0.0149 * * *$ & $0.0156^{* * *}$ & $0.0152 * * *$ & $0.0155^{* * *}$ \\
\hline & $(0.0049)$ & $(0.0049)$ & $(0.0049)$ & $(0.0048)$ & $(0.0049)$ & $(0.0048)$ \\
\hline Debt-to-Assets & -0.0047 & -0.0048 & -0.0001 & -0.0048 & -0.0023 & -0.0049 \\
\hline & $(0.0389)$ & $(0.0392)$ & $(0.0368)$ & $(0.0370)$ & $(0.0372)$ & $(0.0372)$ \\
\hline Sales Growth & 0.0337 & 0.0379 & 0.0431 & 0.0311 & 0.0393 & 0.0322 \\
\hline & $(0.0399)$ & $(0.0398)$ & $(0.0416)$ & $(0.0419)$ & $(0.0422)$ & $(0.0419)$ \\
\hline EBITDA Volatility & -0.0013 & -0.0010 & -0.0014 & -0.0021 & -0.0016 & -0.0019 \\
\hline & $(0.0033)$ & $(0.0032)$ & $(0.0040)$ & $(0.0043)$ & $(0.0041)$ & $(0.0043)$ \\
\hline State Ownership & & $\begin{array}{l}-0.0169 \\
(0.0282)\end{array}$ & & & $\begin{array}{l}-0.0122 \\
(0.0269)\end{array}$ & \\
\hline State Ownership Dummy & $\begin{array}{l}-0.0148 \\
(0.0142)\end{array}$ & & & $\begin{array}{l}-0.0170^{*} \\
(0.0093)\end{array}$ & & \\
\hline ASDI Index & & & $\begin{array}{l}0.4323 * * \\
(0.2102)\end{array}$ & $\begin{array}{l}0.4673 * * \\
(0.2116)\end{array}$ & $\begin{array}{l}0.4381 * * \\
(0.2106)\end{array}$ & $\begin{array}{l}0.4623 * * \\
(0.2128)\end{array}$ \\
\hline $\begin{array}{l}\text { State Ownership Dummy } \\
\text { ASDI Index }\end{array}$ & & & & & & $\begin{array}{l}-0.0369 \\
(0.0338)\end{array}$ \\
\hline Industry Dummies & No & No & No & No & No & No \\
\hline Country Dummies & No & No & No & No & No & No \\
\hline Legal Origin Dummies & Yes & Yes & Yes & Yes & Yes & Yes \\
\hline $\mathrm{N}$ & 146 & 146 & 140 & 140 & 140 & 140 \\
\hline adj. R-sq & 0.362 & 0.359 & 0.378 & 0.380 & 0.374 & 0.378 \\
\hline
\end{tabular}

